\title{
Impact of corruption on the effectiveness of official development assistance in CEMAC Zone
}

\author{
DSANGUE TCHANA Christianne Laure ${ }^{1)}$; Nembot NDEFFO Luc ${ }^{1)}$; \\ DAZOUE DONGUE Guy Paulin ${ }^{2)}$
}

1) Faculty of Economics and Management, University of Dschang, Cameroon

${ }^{2)}$ Faculty of Economics and Management, University of Maroua, Cameroon

e-mail correspondence:dazoue_guy@yahoo.fr

\begin{abstract}
The purpose of this paper is to check the impact of corruption on the link between development assistance and economic growth in the countries of the CEMAC Zone. Thus, from our dynamic panel data model relating economic growth and the explanatory variables including official development assistance and the index of corruption, we use the Generalized Moments Method (GMM) to estimate our model; our sample consisting of the six countries of the CEMAC Zone (Cameroon, Congo, Gabon, Equatorial Guinea, Central African Republic and Chad) and our study period extends from 1996 to 2013. The results indicate that public support for short-term development has no significant effect on growth in the CEMAC Zone; on the contrary, public aid to long-term development has a positive and significant effect on economic growth. Moreover, the variable of interaction between public aid for short-term development and corruption has a negative and significant effect on growth while the long term, has a positive and significant effect on growth. This implies that long-term control strategies against corruption have achieved results such as flows of official development assistance have a positive impact on growth. It therefore appears urgent for the leaders of recipient countries to strengthen the fight against corruption to improve the impact of aid on growth in the CEMAC Zone.
\end{abstract}

Keywords: Official development assistance, Corruption, Economic growth, CEMAC

\section{INTRODUCTION}

The effectiveness of official development assistance in terms of economic growth has sufficiently fuelled many heated debates among politicians, economists and even development specialists. Is official development assistance (ODA) a source of economic growth? For some, as mentioned above, ODA flows have no impact on growth and sometimes can cause damage in the recipient countries. For others, ODA flows stimulate economic growth in recipient countries. For the last category, ODA flows have a positive impact on economic growth, but this positive impact is conditioned by the existence of good institutions, good political environment as well as many other elements (Burnside and Dollar, 2000; World Bank, 1998, Easterly et al., 2004). In poor beneficiary countries, the decrease in aid can be explained by the fact that the granting of aid is increasingly subject to an impressive number of constraints and demands from donors, which are pushing the countries concerned to reduce their demand. These include the conditions of good governance. Aid is only useful and 
effective in low-income countries with good economic policies and quality institutions (Burnside and Dollar, 2000).

Thus, we see indicators of "governance" appear in the new literature of ODA as elements conditioning the impact of ODA flows on economic growth. Indeed, the study of Burnside and Dollar (1997) which was a response to critics of the official development assistance shows that the effectiveness of aid is conditioned by the improvement of governance in recipient countries. For some, good democratic governance allows for better use of ODA that will maximize its productivity; Moreover, democracy is one of donors' criteria for granting ODA; donors will likely give more ODA to countries with better democratic qualities (Akramov, 2012). For Burnside and Dollar (2000), good macroeconomic policies are a prerequisite for ODA to boost growth; they found that ODA boosts growth in countries with good policies and has a negative impact in countries with bad policies. One of the characteristics of good governance (which conditions the effectiveness of aid) is that, the institutions and procedures put in place combat corruption and deviant behaviours. Indeed, governance is of crucial importance for creating an attractive and investment-friendly business environment. It is therefore vital for economic development and, therefore, for tackling poverty. On the other hand, poor governance, especially corruption, is a widespread reality across developing economies in both the public and private sectors (Akpo and Somakpo, 2006). In general, politically stable, transparent, corruption-free developing countries as well as a legitimately established government will receive more ODA; and these funds will be allocated to the country's priority development projects and sectors according to their objectives (Biboh, 2006). Moreover, since 1994, the political climate in the CEMAC Zone (Cameroon, Congo, Gabon, Equatorial Guinea, Central African Republic and Chad) has been characterized by coups d'état or attempts, internal and cross-border conflicts, repeated mutinies, elections that are sources of violence and disputes, the human rights situation is controversial. This context does not promote the growth of the sub-region but helps fuel the fears of investors and the international community.

ODA is often seen as inefficient and rhyme with some waste of taxpayer money. Several authors have recently published books stressing that aid can have adverse effects and act as a brake on the development of recipient countries (Monga 2009, Moyo 2009, Nwokeabia 2009, Tandon 2008). The renewal of this radical critique is challenging especially as it comes this time from African intellectuals. Even if the tone and origin of the authors change, critics say nothing fundamentally new. As early as the 1960s, development aid was challenged by various schools of thought. The terms of the debate have changed little in half a century and, despite criticism, development aid remains a preferred instrument "by default".

Another mischief of international aid is the increase in corruption and bureaucracy. The domestic workforce is moving more towards the growing public sector, and is crowding out the private sector (Bauer, 1972). Public spending increases with aid, and crowds out domestic savings (Mosley, 1996). International aid is, in the best of cases, of zero or almost no effectiveness in alleviating poverty of the Third World, or facilitating development in poor countries (Bauer, 1984, Berg, 1996). Such is the point of view of the liberals, a vision shared by Marxists, but with different fundamentals.

In short, these theses converge on the inability of international aid to promote development or alleviate the suffering of poor countries. While the World Bank sees aid 
as necessary for the growth of developing countries and the eradication of poverty in the world, the current liberal of protestant and the "anti-developmentalists" consider it unfavourable to development. Faced with this, we need to consider empirical analyses of the effectiveness of international aid to see what the facts tell us.

In order to estimate effectiveness of aid in terms of growth, Burnside and Dollar (1997) estimate a growth equation that relates an aid variable to an aid term in interaction with an economic policy indicator. The quality of macroeconomic policies is determined by controlling inflation, balancing the budget and implementing a policy of open trade. The interaction of official development assistance with the economic policy index makes it possible to study the impact of economic policies on the effectiveness of development aid in terms of growth. Their econometric results show a positive and statistically significant coefficient at the $1 \%$ threshold of the cross-term aid with the economic policy indicator. Burnside and Dollar $(1997,2000)$ conclude that aid is only effective in terms of growth in a good macroeconomic environment. In this case, aid is only effective in terms of growth in developing countries with good economic policies. We can then identify the principle of selectivity of the beneficiary countries and the principle of conditionality based on the quality of economic policies.

Burnside and Dollar (2000) conclude that development aid promotes economic growth only in countries that adopt good macroeconomic policies.

Easterly, Levine and Roodman (2004) found that the results obtained by Burnside and Dollar (2000) are not subject of robustness tests. They use the Burnside and Dollar (2000) model for a larger sample. Their estimation results show that the interaction term between the aid received and the economic policy index is statistically insignificant at the $1 \%$ level. They conclude that the effectiveness of development assistance in terms of growth is not dependent on economic policies of the recipient countries.

According to Bauer (2000), aid is a discretionary resource that can be used by the executive to manipulate the electoral process and increase military spending. A recent analysis by Djankov et al (2008) confirms this hypothesis. In addition, the work of Rajan and Subramanian (2007) argues that aid has a corrosive effect on the political institutions of recipient countries.

In view of all the above, the purpose of this paper is to assess the influence of corruption on the official development assistance and economic growth in the CEMAC Zone.

\section{STUDY METHODOLOGY}

We are working on a panel of six CEMAC countries over the period 1996-2013 (18 years) to measure the influence of the two governance indicators on the relationship official development assistance - economic growth. Empirically, it is for us to study two econometric relationships according to the two governance indicators selected. It is based on the literature review that found several variables that are determinants of economic growth. In this chapter, it will therefore be a question for us to present the econometric models in dynamic panel studied, the variables of the model, the source of the data, the applied tests (pre and post-estimation) and the estimation methods.

\section{Specification of the econometric model}

The data we use is from a secondary source and comes from the official databases of the World Bank online including the World Developments Indicators 2014 (WDI, 2014) as well as the Kaufmann Foundation for Governance. 
From the theoretical model of endogenous growth, the empirical model inspired by the work of Burnside and Dollar (2000) will be formulated as follows:

Croiss $_{i, t}=\alpha_{i, t}+\alpha_{1}$ Croiss $_{i, t-1}+\alpha_{2} A P D_{i, t}+\alpha_{3}$ Gov $_{i, t}+\alpha_{4}\left(A P D^{*} G o v\right)_{i, t}+\alpha_{5}\left(A P D^{2} * G o v\right)_{i, t}+\beta^{\prime} X_{i, t}+\varepsilon_{i, t}$

Where:

Croiss $_{i, t} \quad$ is the growth rate of real GDP per capita of country $\mathrm{i}$ in year $\mathrm{t}$.

Croiss $_{i, t-1} \quad$ is the rate of growth of real GDP per capita of country $\mathrm{i}$ in year $\mathrm{t}$ lagged by one period.

Gov $v_{i, t} \quad$ is the governance indicator selected for the country $\mathrm{i}$ in $\mathrm{t}$

$A P D_{i, t} \quad$ is the ratio of inflows of official development assistance and GDP

$\left(A P D^{*} G o v\right)_{i, t}$ is the interaction variable between ODA as a percentage of GDP and the governance indicator selected in the short term;

(APD2Gov) $i, t$ is the interaction variable between ODA as a percentage of GDP and the governance indicator selected in the short term;

$X \quad$ is the vector consisting of other variables identified in the literature as being determinants of growth; these include domestic investment, the openness rate, the human capital of the population growth rate.

The indicator of governance in this work is the level of corruption (corrup), so the equation of the model is as follows:

$$
\text { Croiss }_{i, t}=\rho_{0}+\rho_{1} \text { Croiss }_{i, t-1}+\rho_{2} A P D_{i, t}+\rho_{3} \operatorname{Corrup}_{i, t}+\rho_{4}\left(A P D^{*} \operatorname{Corrup}_{i, t}+\rho_{5}\left(A P D^{2} * \text { Corrup }\right)_{i, t}+\beta^{\prime} X_{i, t}+\varepsilon_{5 i, t}\right.
$$

Where:

Corrup $_{i, t}$ is the level of corruption in the country I in $\mathrm{t}$.

\section{Presentation of variables}

The dependent variable in the model specification is measured by the growth rate of real GDP per capita (Croiss) as an indicator of economic growth. Real GDP per capita is the value of all goods and services produced in an economy during a given period by resident economic agents; its growth measures the economic growth of a country.

The explanatory variables are:

Corruption (Corrup) is our explanatory variable: it measures the extent to which public power is exercised for private purposes, including both bribes and major forms of corruption. Its measurement is between -2.5 and +2.5 . Small values (negative) indicating the corrupt countries and the greatest values for the least corrupt countries. The expected sign is negative.

The domestic investment rate: measured by Gross Fixed Capital Formation (GFCF) relative to GDP. The accumulation of physical capital is expected to have a positive effect on growth.

The degree of openness of the economy: measure the sum of imports and exports relative to GDP (Rivera-Batiz and Romer, 1991). According to the neoclassical theory, the free movement of goods is supposed to boost economic performance and therefore exert a positive effect on economic growth.

Delayed growth rate: This variable is often used in econometric models for long-term growth to test the conditional convergence hypothesis. According to this hypothesis, the long-term growth of the initially poorer countries tends to be stronger than that of the 
initially richer countries. In the long term, there is a convergence of growth rates between rich and poor countries (catch-up effect). The literature informs us that in Africa, initial conditions, as measured by GDP lagged by one or more periods, have a negative impact on GDP. The expected sign of the coefficient is therefore negative.

\section{Estimation method}

The estimation method chosen is based on that proposed by Arellano and Bond (1991): the generalized moments method (GMM). This method is generally used to estimate dynamic panel coefficients (with non-linear variables) and prevent the problems of inverse causality that are often problematic in the study of official development assistance. Here, the model is said to be dynamic because it introduces into the explanatory variable the dependent variable with one or more delays. The GMM is more efficient than other estimators in dynamic paneling according to (Kpodar, 2005). In this method, the series are transformed into first difference and are used to eliminate unobserved specific individual heterogeneity, which corresponds to the specific effects detected by the Breush-Pagan test. The explanatory variables are used as their own instrument.

However, Blundell and Bond (1998) question the properties of this estimator, which they believe can be biased and low precision. The authors propose a "system" approach to overcome these limitations. The method is based on certain conditions of stationarity of the variables of the initial observation. The SGMM estimator combines the standard equation set into first differences with $t-1$ instruments, with a set of additional equations in level with the first differences at $\mathrm{t}-1$ as instruments. This system method, later SGMM, is used for its superiority over the GMM method. However, Kpodar (2005) states that the endogenous variables should be delayed for at least two periods to be used as instruments.

In effect, the basic idea of the generalized moments method (GMM) is the work of Hansen (1982), but the origin of the concept goes back to the work of Sargan (1958). This method consists in combining all the moments in an objective function, it makes it possible to control the effects related to the problems of simultaneity bias, inverse causality and omitted variables (generally applied in economic growth models). The number of moment conditions and the number of parameters to be estimated is identical. So, the conditions that relate to the moments can be exploited not only to test the specification of a model, but also to define its parameters. The GMM dynamic panel method is developed by Arellano and Bond (1991), Arellano and Bover (1995) and Bond and Blundell (1998). This method makes it possible to reconstruct the instruments from the explanatory variables, unlike the other methods of classical instrumental variables (the double least and triple square methods), the latter recommend variables simultaneously satisfying three conditions and which are generally difficult to test. Indeed, the instrumental variable must be theoretically justified, correlated with the independent variable and not correlated with the dependent variable. There are two types of GMM estimators, the first difference GMM estimator and the system GMM estimator. Blundel and Bond (1998) compared the results of two estimators using Monte Carlo simulations. They conclude that the GMM system estimator performs better than the first difference.

The first-difference GMM estimator seeks to eliminate country-specific effects and estimates the first difference by instrumenting the explanatory variables of the firstdifference equation by their lagged-level value of a period or more Making it weak and considerable bias instruments in small samples While the GMM estimator in system 
manages to exceed this limit: it combines the first difference equations with the level equations in which the variables are instrumented by their first differences. The relevance of the GMM system estimator is based on the validity of two tests: the Sargan/Hansen on-identification test of instrument validity (H0: the instruments are valid, that is, uncorrelated with the disturbances) and the autocorrelation test of Arellano and Bond (1991) which assumes a null hypothesis of the absence of autocorrelation of errors of order 1.

We consider panel data, $\mathrm{n}$ individuals observed in $\mathrm{T}$ periods to estimate all our equations whose general form is as follows:

$Y_{i t}=X_{i t} \beta+\varepsilon_{i t}$ with $\varepsilon_{i t}=\alpha_{i}+\mu_{i t}$ or $i=1,2, \ldots, n$ and $t=1,2, \ldots, T$

$Y_{i t}$ defines the dependent variable of country $\mathrm{i}$ at period t, $X_{i t}$ presents the set of explanatory variables and the perturbation which has two components: a fixed or random individual term and, a white noise of variance not correlated to the individual effect.

In the case where the individual effect and the temporal component of the perturbation are not correlated with the explanatory variables, the equations can be estimated by the Ordinary Least Squares or the Quasi-Generalized Least Squares (Dormont, 1989). In the opposite case, it is essential to eliminate this individual effect, either by using an intra-individual model or the difference model. Another important element is that economic growth and official development assistance can be determined simultaneously. The equations to be estimated therefore have potentially correlated regressors and residues. In order to correct the endogeneity biases and to find more robust results, we chose an estimation method with instrumental variables. We use the approach of Arellano and Bover (1995) and we estimate our equations by the Generalized System Moment Method (SGMM). This approach seeks to eliminate the individual effect, it presents an estimator in differences with internal instruments defined by past values of $\quad Y_{i t}$ and of $X_{i t}$.

$Y_{i t}-Y_{i t-1}=\left(X_{i t}-X_{i t-1}\right) \beta+\varepsilon_{i t}-\varepsilon_{i t-1}$

The approach of Arellano and Bover (1995) considers that the instruments are weakly exogenous and are shifted by at least two periods, in other words the perturbations depend only on the present and future values of the instruments. It examines the level equations and considers the assumptions of the following moment and orthogonality conditions:

$$
\begin{aligned}
& E\left(X_{i t} \alpha_{i}\right)=E\left(X_{i t-1} \alpha_{i}\right) \forall t \\
& E\left(\Delta X_{i t-r} \varepsilon_{i t}\right)=0 \text { for } r=1,2, \ldots, t-1 \\
& \left\{\begin{array}{l}
E\left[\left(\Delta Y_{i t}-\Delta X_{i t}\right) X_{i t-r}\right]=0 \text { pour } r \geq 2 \\
E\left[\left(Y_{i t}-X_{i t}\right) \Delta X_{i t-r}\right]=0 \text { pour } r \geq 1
\end{array}\right.
\end{aligned}
$$

\section{Pre-assessment test: IM, Pesaran and Shin stationarity test}

The tests proposed by Im, Pesaran and Shin make it possible to answer the criticism of the homogeneous character of the autoregressive root under the alternative hypothesis. Indeed, these authors were the first to develop a test that allowed under the alternative hypothesis not only a heterogeneity of the autoregressive root, but also a heterogeneity as to the presence of a unit root in the panel. Im, Pesaran and Shin 
consider a model with individual effects and no deterministic trend. In the absence of autocorrelation of residues, this model is written:

$\Delta y_{i, t}=\alpha_{i}+\rho_{i} y_{i, t-1}+\varepsilon_{i, t}$

where the individual effect $\alpha_{i}$ is defined by $\alpha_{i}=\rho_{i} \gamma_{i}$ with $\gamma_{i}$ belonging to the set of real and where $\varepsilon_{i, t} \square N_{i . d}\left(0, \sigma_{\varepsilon, i}^{2}\right)$. The IPS test is a joint test of the null hypothesis of unit root $\left(\rho_{i}=0\right)$ And the absence of individual effects since under the null hypothesis, $\alpha_{i}=0$.

IPS test: $\left\{\begin{aligned} H_{0}: \rho_{i}=0, \forall i=1,2, \ldots, N \\ H_{1}: \rho_{i} \prec 0, \forall i=1,2, \ldots, N_{1} \\ \quad \rho_{i}=0, \forall i=N_{1}+1, N_{1}+2, \ldots, N\end{aligned}\right.$

Under the alternative hypothesis can coexist two types of individuals: for individuals indexed $i=1,2, \ldots, N_{1}$ for which the variable $y_{i, t}$ is stationary and indexed individuals $i=N_{1}+1, N_{1}+2, \ldots, N_{\text {in }}$ which the velocity of the variable $y_{i, t}$ admits a unit root. $\mathrm{N}_{1}$ size of the set of stationary individuals is a priori unknown but verifies $0 \prec N_{1} \leq N$ because if $N_{1}=0$ it then finds the null hypothesis. It is further assumed that the ratio $N_{1} / \mathrm{N}$ verifie $\lim _{N} N_{1} / N=\delta$ with $0 \prec \delta \leq 1$.

Thus, the first advantage of the IPS approach lies in taking into account the heterogeneity of the autoregressive root under the alternative. But that's not the only benefit. As we will see, the authors propose a very simple statistic test based on the average of the individual Dickey-Fuller or Dickey-Fuller augmented statistics.

Under the assumption of no autocorrelation of residuals, IPS derives the asymptotic law of their mean statistic (when $\mathrm{T}$ and $\mathrm{N}$ converge to infinity) but also the semi-asymptotic law when $\mathrm{T}$ is fixed and $\mathrm{N}$ converges to 1 'infinite. In this case, it is indeed possible to derive the exact law of the unit root statistic test for any size $\mathrm{T}$

On the other hand, under the assumption of autocorrelation of the residuals, it is no longer possible to approximate the finite distance rejection thresholds for fixed $\mathrm{T}$ and $\mathrm{N}$ characterize the exact law of the mean statistic for a given size T: IPS derives in this case the asymptotic laws for $\mathrm{T}$ and $\mathrm{N}$ tending towards infinity (either sequentially or along a diagonal) and propose two mean statistics standardized. Once again, we find a normal distribution.

\section{Post Estimation Test: Sargan/Hansen instruments validity test and Arellano and Bond autocorrelation test}

For the validity test of Sargan instruments, if AN is optimally chosen for a given matrix of instruments $\mathrm{Zi}$, the statistic $\mathrm{S}$ of the test is given by:

$$
S=\left[\sum_{i=1}^{N} \varepsilon_{i}^{* \prime} Z_{i}\right] A_{N}\left[\sum_{i=1}^{N} Z_{i}^{\prime} \varepsilon_{i}^{*}\right]
$$

With S following asymptotically, a Chi-square law at (p-k-1) 3 of degree of freedom under the hypothesis $\mathrm{H} 0$ of validity of the instruments. 
Arellano and Bond (1991) have proposed a test that verifies the absence of firstand second-order self-correlation, based on the self-covariance of standardized mean residues and following a reduced normal centered distribution under the hypothesis $\mathrm{H} 0$. Thus, if the distribution is not auto-correlated, this test gives a negative value of the differentiated residues, significant to the first order and non-significant to the second order.

In all, it was a question of giving the nature, the source of the data used and to make a description of the variables as well as the presentation of the models and estimation methods that we will mobilize to analyze the data in our work. From this chapter, we will use for our study the generalized system moments to evaluate the impact of official development assistance on economic growth in the CEMAC. The presentation of the different results resulting from the application of these econometric tools as well as their discussion will be the subject of the next chapter.

\section{RESULTS AND INTERPRETATION}

It will essentially be a question of presenting the results of the tests and estimates made. Also, we will discuss the methods used for assessing the relevance of the model used to estimate the parameters of said model and examine them in accordance with the expectations of the study (study hypotheses and expected variable signs) to the existing literature and to the surrounding context.

Result of IM, Pesaran and Chin stationnarity tests can be seen at Table 1

Table 1. IM, Pesaran and Chin stationnarity tests

\begin{tabular}{lccccc}
\hline \multirow{2}{*}{ Variables } & \multicolumn{2}{c}{ At levels } & \multicolumn{2}{c}{ in difference } & \multirow{2}{*}{ Decision } \\
\cline { 2 - 5 } & Stats & prob & stats & prob & \\
\hline ODA & $-4.83 * * *$ & 0,000 & - & - & $\mathrm{I}(0)$ \\
TX GDP & $-3,71 * * *$ & 0,001 & - & - & $\mathrm{I}(0)$ \\
FDI & $-3.34 * * *$ & 0,004 & - & - & $\mathrm{I}(0)$ \\
IDO & $-2.62 * * *$ & 0,004 & - & - & $\mathrm{I}(0)$ \\
DOE & $-1.54 *$ & 0.062 & - & - & $\mathrm{I}(0)$ \\
DVP Fi1 & $-2.76 * * *$ & 0,003 & - & - & $\mathrm{I}(0)$ \\
Fi2 DVP & $-1.58 *$ & 0.057 & - & - & $\mathrm{I}(0)$ \\
DEMO & -0.98 & 0.162 & $-3.29 * * *$ & 0.005 & $\mathrm{I}(1)$ \\
CORR & -0.928 & 0.176 & $-4.606 * * *$ & 0,000 & $\mathrm{I}(1)$ \\
APD2 & $-5.37 * * *$ & 0,000 & - & - & $\mathrm{I}(0)$ \\
ODA * CORR & $-4.92 * * *$ & 0,000 & - & - & $\mathrm{I}(0)$ \\
APD2 $*$ CORR & $-3.652 * * *$ & 0,000 & - & - & $\mathrm{I}(0)$ \\
\hline NB: $*{ }^{* *}, * * *$ represent the stationarity $10 \%, 5 \%$ and $1 \%$ & & &
\end{tabular}

It can be seen from the table above that all our variables are stationary with the exception of the democracy and corruption variables, which are stationary in first difference.

This correlation table shows that the relationship between official development assistance and the GDP growth rate is negative. Democracy (Demo), note that in this article this variable was not maintained thereafter. Other variables such as corruption, long-term government support are negatively correlated with GDP growth rate. The interaction variables; official development assistance-short-term democracy, official development assistance-short-term corruption, official development assistance-longterm democracy, official development assistance-long-term corruption, are positive. 
This suggests that ODA per say does not have a positive effect on growth, but depending on the democratic and institutional context, this effect can be positive. This highlights the non-linearity of the aid-growth relationship. but we limit ourselves in this article to the role of corruption in the aid-growth relationship.

Table 2. Correlations between variables

\begin{tabular}{|c|c|c|c|c|c|c|c|c|c|c|c|c|c|}
\hline & typib & apd & ide & ido & dœe & dvpfil & dopfi2 & deno & corr & apdsq & apdoor $r$ & apddeno & dsqa $\sim r$ \\
\hline txpib & 1.0000 & & & & & & & & & & & & \\
\hline apd & -0.0557 & 1.0000 & & & & & & & & & & & \\
\hline ide & 0.4372 & -0.0363 & 1.0000 & & & & & & & & & & \\
\hline ido & 0.6311 & -0.2920 & 0.7598 & 1.0000 & & & & & & & & & \\
\hline doe & 0.6176 & -0.3232 & 0.7161 & 0.9496 & 1.0000 & & & & & & & & \\
\hline dopfil & -0.3768 & 0.1360 & -0.1066 & -0.3978 & -0.3844 & 1.0000 & & & & & & & \\
\hline dopfi2 & -0.2402 & -0.1747 & -0.1906 & -0.1868 & -0.2647 & 0.5865 & 1.0000 & & & & & & \\
\hline demo & -0.2766 & 0.1109 & -0.3208 & -0.4844 & -0.4934 & 0.3756 & 0.3010 & 1.0000 & & & & & \\
\hline corr & -0.2349 & 0.0441 & -0.2175 & -0.3877 & -0.3928 & 0.3380 & 0.4351 & 0.7681 & 1.0000 & & & & \\
\hline apdsq & -0.0484 & 0.9175 & -0.0306 & -0.2095 & -0.1976 & 0.1289 & -0.1267 & 0.0878 & 0.0672 & 1.0000 & & & \\
\hline apdcorr & 0.0358 & -0.9772 & 0.0148 & 0.2662 & 0.2902 & -0.1193 & 0.2326 & -0.0686 & 0.0665 & -0.8828 & 1.0000 & & \\
\hline apdieno & 0.0108 & -0.9748 & -0.0214 & 0.2292 & 0.2637 & -0.0796 & 0.1796 & 0.0075 & 0.0120 & -0.8865 & 0.9619 & 1.0000 & \\
\hline apdsqcorr & 0.0467 & -0.9123 & 0.0226 & 0.2055 & 0.1878 & -0.1377 & 0.1556 & -0.0810 & -0.0200 & -0.9895 & 0.9060 & 0.8628 & 1.0000 \\
\hline apdsqdeno & 0.0355 & -0.9137 & 0.0115 & 0.1934 & 0.1856 & -0.1124 & 0.1167 & -0.0469 & -0.0574 & -0.9917 & 0.8804 & 0.9094 & 0.9801 \\
\hline & apdsqdvo & & & & & & & & & & & & \\
\hline apdsqdemo & 1.0000 & & & & & & & & & & & & \\
\hline
\end{tabular}

To get a more precise and robust idea of this correlation, we carried out a correlation significance test whose result is as follows:

Table 3. Significance test correlations

\begin{tabular}{|c|c|c|c|c|c|c|c|}
\hline & Lxpib & apd & ide & ido & doe & dvplil & dvpli2 \\
\hline Lxpib & 1.0000 & & & & & & \\
\hline $\mathrm{apd}$ & -0.0557 & 1.0000 & & & & & \\
\hline ide & $0.4372 *$ & -0.0363 & 1.0000 & & & & \\
\hline ido & $0.6311 *$ & $-0.2920 *$ & $0.7598 *$ & 1.0000 & & & \\
\hline doe & $0.6176 *$ & $-0.3232 *$ & $0.7161^{*}$ & $0.9496^{*}$ & 1.0000 & & \\
\hline dvplil & $-0.3768 *$ & 0.1360 & -0.1066 & $-0.3978 *$ & $-0.3844^{*}$ & 1.0000 & \\
\hline dup I i2 & $-0.2402 *$ & $-0.1787 *$ & $-0.1906 *$ & $-0.1868 *$ & $-0.2647 *$ & $0.5865^{*}$ & 1.0000 \\
\hline demo & $-0.2766 *$ & 0.1109 & $-0.3208^{*}$ & $-0.4844^{*}$ & $-0.4934^{*}$ & $0.3756^{*}$ & $0.3010^{*}$ \\
\hline corr & $-0.2349 *$ & 0.0441 & $-0.2175 *$ & $-0.3877 *$ & $-0.3928^{*}$ & $0.3380^{*}$ & $0.4351^{*}$ \\
\hline apdiqq & -0.0484 & $0.9175 *$ & -0.0306 & $-0.2095 *$ & $-0.1976^{*}$ & 0.1289 & -0.1267 \\
\hline apdkorr & 0.0358 & $-0.9772 *$ & 0.0148 & $0.2662^{*}$ & $0.2902^{*}$ & -0.1193 & $0.2326^{*}$ \\
\hline apditemo & 0.0108 & $-0.9788^{*}$ & -0.0214 & $0.2292^{\star}$ & $0.2637^{*}$ & -0.0796 & $0.1796^{*}$ \\
\hline aptsqcorr & 0.0467 & $-0.9123 *$ & 0.0226 & $0.2055 *$ & 0.1878* & -0.1377 & 0.1556 \\
\hline \multirow[t]{2}{*}{ aptsquemo } & 0.0355 & $-0.9137 *$ & 0.0115 & $0.1934^{*}$ & $0.1856^{*}$ & -0.1124 & 0.1167 \\
\hline & demo & corr & apdsq & apdcoer & aptidemo & apdsqar a & apdisqi-o \\
\hline demo & 1.0000 & & & & & & \\
\hline corr & $0.7681 *$ & 1.0000 & & & & & \\
\hline apdisq & 0. 0878 & 0.0672 & 1.0000 & & & & \\
\hline apdkort & -0.0686 & 0.0665 & $-0.8828 *$ & 1.0000 & & & \\
\hline apditemo & 0.0075 & 0.0120 & $-0.88655^{*}$ & $0.9619 *$ & 1.0000 & & \\
\hline aptsqcort & -0.0810 & -0.0200 & $-0.9895 *$ & $0.906 a^{*}$ & 0. $8828^{*}$ & 1.0000 & \\
\hline aptsqiemo & -0.0469 & -0.0574 & $-0.9917 *$ & $0.8804 *$ & $0.9094^{*}$ & $0.9801^{*}$ & 1.0000 \\
\hline
\end{tabular}

$\underline{N B}^{*}$ Reflects the significance at $10 \%$ 
The significance test of correlation suggests that there is no significant correlation between GDP growth rates and all of the above variables.

Recognizing that mechanical correlations can be constructed between variables, we used a much more robust econometric methodology to determine the impact of ODA on growth in a context of democracy and in a context of corruption. The aim of this article was determined the role of corruption in the relationship ODA Economic growth in the CEMAC Zone. Before proceeding with the interpretation of our variables, it is necessary to assess the relevance and robustness of the entire model.

Table 4. Effect of corruption in the APD-growth relationship

\begin{tabular}{|c|c|c|}
\hline \multicolumn{3}{|c|}{ Dependent Variable: txpibpt ( governance $=$ corruption) } \\
\hline Variables & Coefficients & $\mathrm{t}$ \\
\hline txpib (-1) & $\begin{array}{l}.1152 * * * \\
(.0304)\end{array}$ & 3.79 \\
\hline apd & $\begin{array}{r}-6.9307 \\
(4.4927)\end{array}$ & -1.54 \\
\hline corr & $\begin{array}{l}16417 \text { **** } \\
(4.3960)\end{array}$ & 3.73 \\
\hline apdsq & $\begin{array}{l}.6123 * \\
(.33053)\end{array}$ & 1.85 \\
\hline apdcorr & $\begin{array}{c}7354 * * \\
(3.6027)\end{array}$ & -2.04 \\
\hline apdsqcorr & $\begin{array}{l}.60099 * * \\
(.28344)\end{array}$ & 2.12 \\
\hline ide & $\begin{array}{r}.02049 \\
(.12563)\end{array}$ & 0.16 \\
\hline ido & $\begin{array}{r}.11305 \\
(.09188)\end{array}$ & 1.23 \\
\hline doe & $\begin{array}{r}.0625 \\
(.04116)\end{array}$ & 1.52 \\
\hline dvpfi1 & $\begin{array}{l}.91134 \text { ** } \\
(.3917)\end{array}$ & -2.33 \\
\hline cons & $\begin{array}{l}22.9658 * * \\
(8.8741)\end{array}$ & 2.59 \\
\hline Observations & & \\
\hline Instruments & & \\
\hline Wald (chi-square) & & \\
\hline Prob (Wald) & & \\
\hline Stat Sargan & & \\
\hline Prob (Sargan) & & \\
\hline $\mathrm{AR}(2)$ & & \\
\hline
\end{tabular}

Source: estimation of the author using Stata 13

$\mathrm{NB}: *, * *$ and $* * *$ represent the significances of $10 \%, 5 \%$ and $1 \%$ respectively

The estimate whose results are contained in the table above was made from a sample of 90 observations. The probability associated with the Wald statistic $(p=$ 
$0.0000<0.01)$ is below the $1 \%$ threshold, suggesting that the model is globally significant; the Wald statistic (Wald $=1140.64$ ) provides the same information on the overall significance of the model. These two indicators therefore show that the model is globally significant. On the other hand, the number of instruments $(24<90)$ is less than the number of observations suggesting that our regression is robust. Our estimation suggests, through the Arellano and Bond autocorrelation test, a lack of second-order autocorrelation $(p=0.93>0.05)$ and also through the Sargan instruments overidentification test that our instruments are valid because the probability associated with this test is greater than the significance threshold, which may be $1 \%, 5 \%$ or $10 \%(\mathrm{p}=$ 0.93). All these elements lead us to validate the results that these estimates give us.

Of the ten (10) explanatory variables of which our model is made (txpib (-1), apd, corr, apdsq, apdcorr, apdsqcorr, ide, ido, doe, dvpfi1), six of them are significant (txpib (-1), corr, apdsq, apdcorr, apdsqcorr, dvpfi1) and four of them are non-significant (apd, ide, ido, doe). In other words, the lagged value growth rate, long-term official development assistance, corruption, short-term official development assistance associated with corruption, long-term official development assistance associated with corruption, financial development has a statistically significant effect on economic growth in CEMAC. On the other hand, official development assistance (ODA), foreign direct investment (FDI), the degree of trade openness of the economy (doe), domestic investment (ido) have no effect significant impact on the growth of the CEMAC countries. Examination of these significant individual variables suggests that: the delayed growth rate has a positive and significant effect on the current growth rate; Indeed, an increase in the growth rate of the previous period by 1 point will lead to an increase in the growth rate of the current period of 0.11 points. This coefficient does not satisfy the conditional convergence assumption that the coefficient of the lagged variable is negative and significant to ensure the catch-up effect.

Short-term official development assistance has no significant effect on growth in CEMAC; on the other hand, long-term official development assistance has a positive and significant effect on growth; in fact, an increase in long-term aid of 1 point will lead to an increase in growth of 0.61 points; This implies that a substantial increase in the volume of aid will be likely to have a significant impact on growth. This result is consistent with those found by Burnside and Dollar (2000), World Bank (1998).

The interaction variable between short-term ODA and corruption has a negative and significant effect on growth; in fact, an increase in aid of 1 point will lead to a decrease in growth of 7.35 points. This implies that in a context of advanced corruption, ODA will be a drag on economic growth because these flows are diverted for individual purposes and does not serve the cause they are supposed to serve. These results are consistent with those found by Raghuram and Subramanian (2005) who considered the negation of a positive effect of ODA on growth.

The interaction variable between long-term ODA and corruption has a positive and significant effect on growth; in fact, an increase in long-term aid of 1 point will lead to an increase in growth of 0.6 point. This implies that, in the long run, anti-corruption strategies will have achieved results such that ODA flows have a positive impact on growth. This confirms the studies conducted by Lensink and White (2000), Dalgaard and Hansen (2001), which led to political implications. Indeed, for them, aid is more effective in a good macroeconomic and institutional environment with good governance. 
Financial development has a positive and significant effect on economic growth in the CEMAC Zone; in fact, an increase in APD 1 point will cause an increase in growth of 0.9 points.

\section{CONCLUSION}

The general conclusion from these estimates show that public aid has no significant effect on growth in the CEMAC, but that in the context of corruption, it would have a negative effect on growth. However, in the long term, the anti-corruption efforts undertaken by the zone states will allow the increase in FDI to have a positive and significant effect on growth in this context. Studies by Lensink and White (2000), Dalgaard and Hansen (2001) have led to political implications. Indeed, for them, aid is more effective in a good macroeconomic and institutional environment with good governance.

\section{REFERENCES}

Adom D. A. (2012), "Investigating the impact of intra-regional trade and aid is per capita income in Africa: case study of the ECOWAS." Department of Economics, Estern Illinois University, 600Lincoln Avenue, Charleston 61920, USA.

V. Ahmed and Abdul Wahab M. (2011), "Foreign aid and economic growth: evidence from Pakistan 1972-2010". MRPA No. 30344, posted 24. April 2011.

Akpo and Somakpo. (2006) "Governance and efficiency of development finance policies

Akramov K. (2012), "Foreign aid allocation Governance 'and Economic Growth". International Food Policy Research Institute. November 2012.

Alesina, A. and D. Dollar (2000). "Who Gives foreign aid To Whom and why ?," Journal of Economic Growth, Vol. 5, p.33-63.

Amewoa A.K. (2008). The ODA allows -it development in sub-Saharan Africa, Limoges university press.

Armah ES (2010), "Does political stability Improve the aid-growth relationship? A panel evidence we selected sub- Saharan African countries ". African Review of Economics and Finance, Vol. 2 December 2010.

Armah ES (2012), "Assessing and marketing strategies helped to Stimulate Economic Growth in Sub Saharan Africa." Doctor of Philosophy Thesis in Agricultural Economics and Consummer; University of Illinois, Urbana.

Aubut J. (2004), "The good governance agenda: Who Wins and Who Loses. Some empirical evidence for 2001 ". Destiny Development Studies Institute; Working Paper Series; 2004.

World Bank (1998) Assessing Aid: What Works, What Does not, and Why? Oxford University Press, New York.

Bashir (2013) " Foreign Assistance and Economic Growth in Nigeria: The Two-Gap Model Framework"American International Journal of Contemporary Research, Vol. 3 No. 10;

Ben Saad (2012). "What effectiveness of official development assistance? If GHANA"Master Thesis 1

Biboh NH (2006), "Foreign aid, governance quality, and economic growth in developing countries." Thesis for Master of Philosophy in Environmental and Development Economics 
Brautigam \& Knack (2004) "Foreign Aid, Institutions, and Governance in Sub-Saharan Africa"

Bulír A. Lane and T. (2002). "Aid and Fiscal Management."IMF Working PaperWP / 02/112. Washington, DC.

Bulír, A. J. and Hamann, (2003). "Aid Volatility: An Empirical Assessment" IMF Staff Papers50: 65-89.

Bulir, A. J. and Hamann, (2006). "Volatility of Development Aid: From the Frying Pan Into the Fire?" IMF Working Paper. WP / 06/65. Washington, DC.

Bulír, A. J. and Hamann, (2001). "How are Volatile and Unpredictable Aid Flows, and what are the Policy Implications?"IMF Working PaperWP / 01/167. Washington, DC.

C. Burnside and Dollar D. (2000). "Aid, Policies and Growth". American Economic Review, 90 (4), 847-868.

Burnside, C., and D. Dollar (2004). "Aid, Policies, and Growth. Revisiting the Evidence" Policy Research Working Paper Series 3251, The World Bank.

Burnside, C. and D. Dollar, (1997). "Aid, Policies, and Growth," Policy Research Working Paper, No. 1777. Washington DC: World Bank. Revised Version published in American, Economic Review, September 2000.

Boone, P. (1994). "The impact of foreign aid is savings and growth," Center for Economic Performance Working Paper, No. 677, London School of Economics.

Boone (1995). "Politics and the effectiveness of foreign aid"Center for economic performance Discussion Paper no. 272.

MA Clemens, Radelet S. and R. Bhavnani (2004). "Counting Chickens When They Hatch: The Short Term Effect of Aid on Growth," Working Paper No. 44, Center for Global Development.

Necklace., P., (1999), "On the Economic Consequences of Civil War ', Oxford Economic Papers 51, 168-83.

Collier, P. and J. Dehn, (2001). "Aid Shocks and Growth", World Bank Working Paper No. 2688, Washington, DC

Dalgaard, CJ. and H. Hansen (2001). "We Aid Growth and Good Policies". Journal of Development Studies 37 (6): 17-41.

C. Dalgaard, Hansen and Tarp H. F. (2002). "On the Empirics of Foreign Aid and Growth." CREDIT Research Paper 02/08. University of Nottingham, England.

Dalgaard, CJ, Hansen, H. and F. Tarp (2004). "On the empirics of foreign aid and growth," Economic Journal, vol.114, p.191-216.

Djankov, S., and R. Montalvo JG, Querol (2008). "The Curse of Aid," Journal of Economic Growth 13: 169-194.

Dollar, D. and W. Easterly, (1999). "The Search for the Key: Aid, Investment and Policies in Africa". Journal of African Economies, 8 (4), 546-77.

Doucouliagos, H. and M. Paldam (2009). "Conditional aid effectiveness: a metaanalysis," Journal of International Development 21 (7): 1582-1601.

Easterly, W., R. Levine, and D. Roodman (2004). "Aid, Policies, and Growth: How" American Economic Review 94 (3): 774-780.

Easterly, W and T. Pfütze (2008). "Where Does the Money Go? Best and Worst Practices in Foreign Aid "The Journal of Economic Perspectives 22 (2): 29-52

Easterly, W. (2006). The White Man's Burden: Why the West's Efforts to Aid the Resthave done so Little Good. New York: The Penguin Press. 
Easterly, W. (2003). "Can Aid Buy Growth?" Journal of Economic Perspectives 17 (3) 23-48.

Feulefack, KL (2011). "Effects of Foreign Direct Investment and Governance in the Economic Growth in Cameroon" Thesis Master of Science in Economic Sciences, University of Dschang.

Fischer S. (1993), "The Role of Macroeconomics Factors in Growth," Journal of Monetary Economics 32: 485-512.

N. Gemmell and McGillivray M. (1998). "Aid and Tax Instability and the Government Budget Constraint in Developing Countries", CREDIT Research Paper 98/1. the University of Nottingham, England.

Golden I. Rogers and H. Stern N. (2003), "The role and effectiveness of development aid: Lessons from the World Bank Experience". Department Economics Vice Presidency; World Bank.

Gomanee K. Girma and Morrissey O. (2002). "Aid and Growth in Sub-Saharan Africa: Accounting for Transmission Mechanisms", CREDIT Research Paper 02/05. the University of Nottingham, England.

Gomanee, K. Girma, S. and O. Morrisey (2005). "Aid and growth in Sub-Saharan Africa: accounting for Transmission Mechanisms," Journal of International Development, vol.17, no.8, p.1055-1075.

Guillaumont, P. and L. Chauvet, (2001). "Aid and Performance: A Reassessment". Journal of Development Studies, 37 (6), 66-87.

Gupta S. C. Pattillo and Wagh S. 2006. "Are Giving Donor Countries More or Less Aid? IMF Working Paper WP / 06/1, Washington, DC.

H. Hansen and Tarp, F., (2000). "Aid and Growth Regressions", CREDIT Research Paper 00/07. the University of Nottingham, England.

Hansen H.et Tarp F. (1999). "Aid Effectiveness Disputed", CREDIT Research Paper 99/10. the University of Nottingham, England.

Hansen and Tarp H. F., (2000). "Aid Effectiveness Disputed" Journal of International Development, 12 (3), 375-98.

Hansen and Tarp H. F., (2001). "Aid and Growth Regressions" Journal of Development Economics, 64 (2), 547-70.

Hatemi and Irandous (2005). "Foreign aid and Economic Growth: new evidence from Panel cointegration "Journal of Economic Development, Volume 30, Number 1

D. Kaufmann, Kraay A. (2002), "Growth without governance". World Bank Working Paper Series.

D. Kaufmann, Kraay, A. and M. Mastruzzi (2003), "Governance Matters III: Governance Indicators for 1996-2002". Draft for Comment; The World Bank.

D. Kaufmann, Kraay, A. and Zoido - Lobaton P. (1999), "Governance Matters." Policy Research Working Paper; The World Bank. October 1999.

Karras, G. (2006) "Foreign aid and long-run economic growth: empirical evidence for a panel of Developing Countries," Journal of International Development, vol.18, no.7, p.15-28.

Levy, V. (1988), Aid and Growth in Sub-Saharan Africa: The Recent Experience. European Economic Review 32 (9): 1777-1795.

Lensink R. and H. White, (2000)"Assessing Aid: A Manifesto for Aid in the 21st Century? " Oxford Development Studies 28 (1): 5-17.

McGillivray, M. and O. Morrissey (2004). "A Review of Evidence on the Effects of Fiscal Aid ", CREDIT Research paper, No. 01/13, University of Nottingham. 
McGillivray, M. Feeney, S. Hermes, N. and R. Lensink (2006)"Controversies over the impact of development aid: it works; it does not; it can, aim That depends, "Journal of International Development, Vol. 18, no.7, p.1031-1050.

Moyo, D. (2009). Dead Aid: Why aid is not working and how there is a better way for Africa, Farrar, New York.

Odedokun, M.,(2003). "Analysis of Deviations and Delays in Aid Disbursements", WIDER Discussion Paper No. 2003/26.

Papanek, GF (1973). "Aid, Foreign Private Investment, Savings, and Growth in Less Developed Countries ", Journal of Political Economy 81 (1): 120-30.

Rajan, R. and A. Subramanian (2007). "Does Aid Affect Governance ?," American Economic Review 97: 322-327.

Rajan and Subramanian (2008). "What does the Cross-Country Evidence Really Show" The Review of Economics and Statistics, November 2008, 90 (4): 643-665

Reports FRANC area from 1996 to 2014

Rajan, R. and A. Subramanian (2007). "Does Aid Affect Governance ?," American Economic Review 97: 322-327

Rajan, RG and A. Subramanian (2011). "Aid, Dutch disease, and Manufacturing Growth," Journal of Development Economics, 94 (1), 106-118.

Roodman, MD (2006) "How to Do xtabond2: An Introduction to Difference and System GMM in STATA" Center for Global Development Working Paper Number 103.

United Nations Development Program, (2005). Human Development Report 2005: International Cooperation at the Crossroads: Trade and Security in an Unequal World. New York: UNDP.

World Bank, (2001). "Cameroon: Country Assistance Evaluation. Report No. 21788, Operations Evaluation Department, World Bank.

World Bank, (2001b). "Global Development Finance: Building Coalitions for Effective Development Finance," Washington, DC. 